\begin{tabular}{|c|c|}
\hline \multirow{3}{*}{ 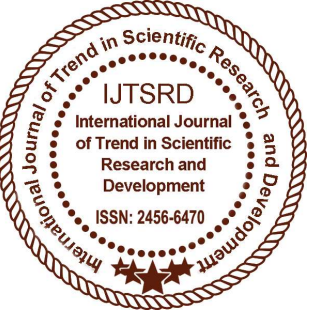 } & $\begin{array}{l}\text { International Journal of Trend in Scientific } \\
\text { Research and Development (IJTSRD) }\end{array}$ \\
\hline & International Open Access Journal \\
\hline & ISSN No: 2456 - 6470 | www.ijtsrd.com | Volume - 2 | Issue - 5 \\
\hline
\end{tabular}

\title{
Assessment of Bioactive Activity of Blackberry Seed Extract
}

\section{Most. Sajeda Begam}

Student, Department of Food Technology \& Rural Industries, Faculty of Agricultural Engineering \& Technology, Bangladesh Agricultural University, Mymensingh 2202, Bangladesh.

\section{Md. Nur Hossain}

Senior Scientific Officer, Institute of Food Science and Technology, Bangladesh Council of Scientific and Industrial Research, Dhaka 1205, Bangladesh.

\begin{abstract}
Pabitra Chandra Das
Lecturer, Department of Chemical and Food Process Engineering, Faculty of Mechanical Engineering, Rajshahi University of Engineering \& Technology, Rajshahi 6204, Bangladesh.
\end{abstract}

\section{Abdullah Iqbal}

Professor, Department of Food Technology \& Rural Industries, Faculty of Agricultural Engineering \& Technology, Bangladesh Agricultural University, Mymensingh 2202, Bangladesh.

\section{ABSTRACT}

The aim of this study was to determine the bioactive activity of the blackberry (Rubus laciniatus) seed extracts. Total phenolic and total antioxidant activity of blackberry seed extracts were assessed with respect to two extracting solvents (absolute ethanol and absolute acetone) and two extracting techniques (hot extraction at $40^{\circ} \mathrm{C}$ and cold extraction at $26^{\circ} \mathrm{C}$ ). Proximate analysis showed that blackberry seeds contained $12.12 \%$ moisture, $8.00 \%$ protein, $0.74 \%$ fat, $2.15 \%$ ash and $76.99 \%$ total carbohydrate. The antioxidant activities of blackberry seeds were determined by evaluating total phenolic activity by gallic acid equivalent (GAE), total antioxidant capacity by ascorbic acid equivalent (AAE) content and ferric reducing powder assay. The tested sample showed variable amount of total phenolic content (33.21-56.56 $\mathrm{mg} \mathrm{GAE} / \mathrm{g}$ of dry extract), total antioxidant capacity (75.46-82.42 AAE/g) and reducing power $(0.23-0.26)$ depending on different extraction techniques and solvents used. Higher amount of extract, total antioxidant capacity and reducing power were obtained for hot extraction technique. As compared to cold extraction technique, higher extract yields $(7.48 \%$ vs $7.19 \%$ for ethanol and $4.35 \%$ vs $4.28 \%$ for acetone) and other properties were obtained by hot extraction for a given solvent. Ethanol extract with hot extraction technique gave total phenolic content as $56.56 \mathrm{mg} \mathrm{GAE} / \mathrm{g}$ of dry extract, total antioxidant capacity as $82.42 \mathrm{AAE} / \mathrm{g}$ and reducing power as 0.26 at extract concentration of 250 $\mu \mathrm{g} / \mathrm{ml}$. The overall observations of the present experiment indicated that hot ethanol extract of blackberry seeds have strong antioxidant property and bioactive activity.

KEYWORD: Blackberry seed, Total phenolic content, Antioxidant activity, Hot and cold extraction.

\section{INTRODUCTION}

Naturally available fruits are great sources of different antioxidant compounds like polyphenols, phenolic acids and flavonoids which protect people from different degenerative diseases like cardiovascular diseases and cancer by scavenging free radicals such as peroxide, hydro peroxide of lipid hydroxy (Kaume et al., 2012 and Subramanion et al., 2011).

Antioxidants are also helpful to prevent or inhibit oxidation processes in human body as well as in food products. Natural antioxidants are available in almost all edible plant products and are stable parts of nutrition. According to Haleem et al. (2008), most of the beneficial properties of phenolic compounds are attributed due to their antioxidant activity. Besides playing the role as a functional component, antioxidants also help the food products in retaining their sensorial quality, e.g. color, texture and taste, as 
well as their nutritional quality through preventing the oxidation of essential fatty acids (Coda et al., 2012).

Natural antioxidant compounds isolated from different sources are now receiving a special attention (Ghosal et al., 2003) and are good alternatives for synthetic antioxidants to the fresh or processed foods (Arabshahi-Delouee and Urooj, 2006). There is a growing demand for natural antioxidants because of toxicological and carcinogenic effects of synthetic antioxidants such as butylated hydroxyanisole (BHA), butylated hydroxytoluene (BHT) on animals (Amarowicz et al., 2010). The artificial antioxidant compounds (e.g. BHA and BHT) have a limited allowance for food due to their potential cancerogenicity (Jayaprakasha et al., 2003). Recently consumers often reject food products that are enriched with synthetic antioxidants because some of the synthetic antioxidants may exhibit toxicity and require high manufacturing costs but show lower efficiency than natural antioxidants (Saha et al., 2011).

In different fruit and beverage industries, during the processing of juice and jam, a large amount of their by-products (mostly of the seeds) is produced. Currently, industrial management have shown interest on developing value added products from the waste generated from both the food and agricultural processing industries (Balasundram et al., 2006). The waste products including seeds, peels, stalks, stems, and leaves of plants contain substantial amount of phenolic which can be used as important and cheap sources of natural antioxidants for pharmaceutical, cosmetic, and food application (Bucic-Kojic et al., 2009).

Plant phenolic compounds are a major source of natural antioxidants and are distributed in fruits, seeds, leaves, vegetables, barks, roots, and flowers of plants (Marinova and Yanishlieva, 2003; Wang and Lin, 2000). Antioxidant compounds have been identified in the seeds of grape (Llobera, 2012), citrus (Baydar et al., 2006), mango (Maisuthisakal, 2009), canola (Ozen et al., 2011), and sunflower (Zhao et al., 2011). Singh and Rajini (2004) mentioned that researcher are seeking newer sources of antioxidants especially from plants while Prasad et al. (2011) noticed that in recent years, underutilized fruits are getting special focused in research and development. But due to lack of commercial applications, fruit seeds have not received much attention as antioxidant sources.

In Bangladesh, blackberry (Rubus laciniatus) is an important seasonal fruit and the annual production is approximately 22,000 metric ton. After consumption of blackberry fruits, the seeds are considered as wastage. But its seeds are great source of antioxidants including ellagic acid, tannins, ellagitannins, gallic acid, anthocyanins, and cyanidins (Huang et al., 2012).

Antioxidants have become a popular research topic because they cannot be generated by the human body and hence have to be taken through the diet. Many fruits and vegetables have been found to be rich sources of antioxidants. Since a large portion of the human diet is based on fruit and vegetables, it is important to understand the biological and biochemical interactions between these dietary antioxidants and living systems. Seed extracts showed higher antioxidant activity than fruit extracts. There is a growing demand for natural antioxidants because of its safety to human health and so a suitable solvent and extraction technique are needed to preserve the antioxidant properties. Thus, the purpose of this study was to determine the effect of the solvents used in extraction techniques on the antioxidant activity of blackberry seeds while based on above views this study has been taken with the following specific objectives: (a) to analyze chemical and proximate composition of blackberry seed, (b) to identify the effect of extraction solvent and techniques on the antioxidant activity of blackberry seed and (c) to compare among the effect of extraction methods on the antioxidant activity of blackberry seed.

\section{MATERIALS AND METHODS}

The experiment was conducted in the laboratories of the Department of Food Technology and Rural Industries and Dr. Mohammad Hussain Central Laboratory, Bangladesh Agricultural University, Mymensingh and in the laboratory of Chemical Research Division of the Institute of Food Science and Technology, Bangladesh Council of Scientific and Industrial Research (BCSIR), Bangladesh.

\section{Materials}

Blackberries were collected from the local market of Mymensingh. AR grade chemicals like absolute ethanol, absolute acetone, ammonium molybdate, sodium phosphate, L-ascorbic acid, gallic acid, sodium carbonate, potassium ferricyanide, trichloroacetic acid (TCAA), ferric chloride $\left(\mathrm{FeCl}_{3}\right)$, sulphuric acid etc. were used for the experiment and were supplied from the laboratory stock. 


\section{Preparation of sample}

First the seeds were separated and sun dried under the sun properly. Then they were grinded with lab grinder. After that they were taken out and fine powder of blackberry seeds were separated by passing the powder through 30 mesh size sieve. The powdered sample was then stored in a poly bag and kept in refrigerator for further analysis.

\section{Chemical composition analysis}

The blackberry seeds were analyzed for their chemical component like moisture, ash, fat, protein and total carbohydrate. AOAC (2005) was used for determination of moisture content while AOAC method (2012) for total ash content, AOAC method 7.045 (2005) for crude fat content and protein was determined by Micro-Kjeldahl method described by AOAC (2005). Carbohydrate content of the samples was determined as total carbohydrate by subtracting the measured protein, fat, ash and moisture from 100 (Srivastava and Sanjeev, 2002).

\section{Extraction procedure}

For cold extraction, two clean and dried conical flasks were taken. $25 \mathrm{gm}$ of dried blackberry seed powder was taken in each conical flask. Then $200 \mathrm{ml}$ of ethanol was added to one conical flask and $200 \mathrm{ml}$ of acetone was added to another one. After that both of the conical flasks were put in a continuous shaker machine at a constant temperature of $26^{\circ} \mathrm{C}$ for 48 hours.

For hot extraction, the above procedure was followed but using a temperature controlled shaker machine at $40^{\circ} \mathrm{C}$ for $48 \mathrm{hrs}$. Then all the obtained acetone and ethanol extract were filtered through a filter paper and the filtrate was then dried in a vacuum oven at reduced pressure and at a temperature of $40^{\circ} \mathrm{C}$. The dried extract of blackberry seed sample was weighed in an electric balance and stored in vial for further analysis.

\section{Phytochemical screening test}

\section{Methodolgy for determination of Total Phenolic Content (TPC)}

The TPC of the extracts was determined by following the modified Folin-Ciocaltu method (Imran and Khan, 2014). In short, $1.0 \mathrm{ml}$ of each extract $(1 \mathrm{mg} / \mathrm{ml})$ was mixed with $5 \mathrm{ml}$ Folin-Ciocaltu reagent $(1: 10 \mathrm{v} / \mathrm{v}$ in distilled water) and $4 \mathrm{ml}$ of $7.5 \%$ sodium carbonate. The mixture was vortexed for $15 \mathrm{sec}$ and allowed to stand for $30 \mathrm{~min}$ at $40^{\circ} \mathrm{C}$ for color development. Then the absorbance was measured at $765 \mathrm{~nm}$ with a spectrophotometer. Gallic acid was used as a standard for the calibration curve. While preparing the standard curve the concentration of gallic acid were $0,0.25$, $0.50,0.75,1.00 \mathrm{mg}$ per $\mathrm{ml}$ solutions of gallic acid in methanol: water $(50: 50, \mathrm{v} / \mathrm{v})$. The standard curve was prepared by using the method as mentioned above except the sample was absent there. According to the obtained data, the concentration vs. absorbance curve of gallic acid was drawn which is shown in Figure 1.

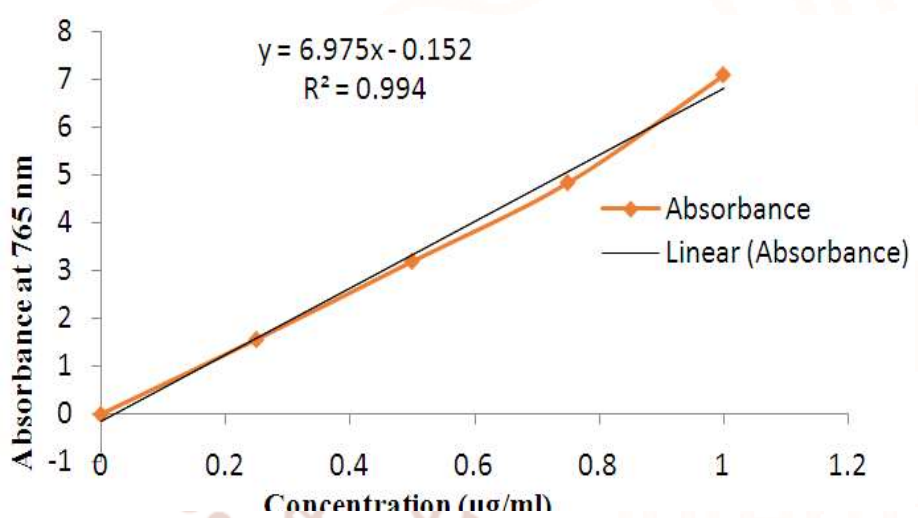

Figure 1: Concentration vs. Absorbance (at 765nm) curve of Gallic acid.

\section{Antioxidant activity tests}

The antioxidant activity of different extracts of blackberry seed was determined by following two methods: total antioxidant capacity and reducing power assay.

\section{Total Antioxidant Capacity determination}

$50 \mathrm{mg}$ of each of the extracts (acetone, ethanol) were weighed and mixed in $50 \mathrm{ml}$ of acetone and ethanol respectively and mixed completely by using sonicator and vortex machine stirring. Thus the concentration of each solution would be $1000 \mu \mathrm{g} / \mathrm{ml}$ (stock solution). Then different solutions were carried out to obtain the concentrations of $20,40,60,80,100$ and $250 \mu \mathrm{g} / \mathrm{ml}$ from the stock solution of acetone and ethanol extracts for determining antioxidant activities of blackberry seed. Total antioxidant activity of the extract was calculated by the phosphomolybdenum assay method which is based on the reduction of Phosphate-Molybdenum, Mo (VI) to PhosphateMolybdenum, Mo (V) by the extract and subsequent formation of a green phosphate-Mo (V) complex in acidic condition (Matthias et al., 2015). The extract $(2.0 \mathrm{mg} / \mathrm{ml}, 0.3 \mathrm{ml})$ was allowed to mix up with 3.0 $\mathrm{ml}$ of reagent solution $(0.6 \mathrm{M} \mathrm{H} 2 \mathrm{SO} 4,28 \mathrm{mM}$ $\mathrm{Na}_{3} \mathrm{PO}_{4}, 4 \mathrm{mM}$ ammonium molybdate) and the reaction mixture was incubated at $95^{\circ} \mathrm{C}$ for 90 minutes. After cooling at room temperature, the absorbance of the solution was measured at $695 \mathrm{~nm}$ 
using a UV-Visible spectrophotometer against an appropriate blank. The antioxidant activity was expressed as the number of gram equivalents of ascorbic acid. Concentration vs. absorbance (695 nm) curve of ascorbic acid for determination of total antioxidant capacity is shown in Figure 2. The standard curve was prepared by using the same method as mentioned above except the sample.

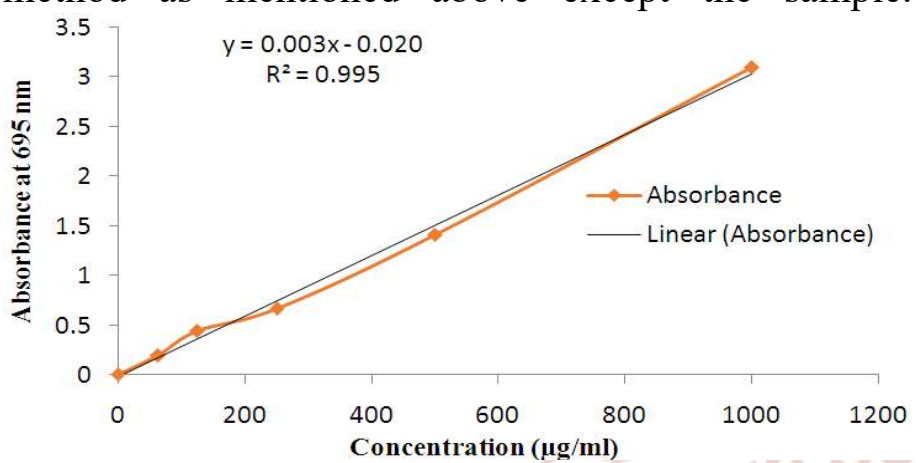

Figure 2: Concentration vs. Absorbance (at 695nm) curve of ascorbic acid for determination of total antioxidant capacity.

\section{Reducing power assay}

This assay was determined according to the method reported by Dehpour et al. (2009). Briefly, $10 \mathrm{ml}$ of acetone and ethanol extracts solution of different concentrations was mixed with $2.5 \mathrm{ml}$ of potassium ferricyanide $\left[\mathrm{K}_{3} \mathrm{Fe}(\mathrm{CN})_{6}\right](1 \% ; \mathrm{w} / \mathrm{v})$ and $2.5 \mathrm{ml}$ of phosphate buffer $(0.2 \mathrm{M}$; $\mathrm{pH} 6.6)$. The mixture was incubated at $50^{\circ} \mathrm{C}$ for $20 \mathrm{~min}$. After that the reaction was terminated by the addition of $2.5 \mathrm{ml}$ of trichloroacetic acid $(10 \% ; \mathrm{w} / \mathrm{v})$. Then the mixture was centrifuged at $3000 \mathrm{rpm}$ for $10 \mathrm{~min}$. Finally the supernatant solution $(2.5 \mathrm{ml})$ was mixed with distilled water $(2.5 \mathrm{ml})$ and ferric chloride $(0.5 \mathrm{ml} ; 0.1 \%$, w/v) solution. Then the absorbance was measured at 700 $\mathrm{nm}$ against a blank reading. Increased absorbance value of the reaction mixture indicates increased of reducing power of the extracts. Three replicates were made for each of the tested sample.

\section{RESULTS AND DISCUSSION}

\section{Composition of blackberry seed}

The blackberry seed was analysed for the moisture, ash, protein, fat and total carbohydrate and the obtained average values of triplicate determination are shown in Table 1.

Table 1: Composition of blackberry seed (experimented)

\begin{tabular}{|c|c|c|c|c|}
\hline $\begin{array}{c}\text { Moisture } \\
(\%)\end{array}$ & $\begin{array}{c}\text { Protein } \\
(\%)\end{array}$ & $\begin{array}{c}\text { Fat } \\
(\%)\end{array}$ & $\begin{array}{c}\text { Ash } \\
(\%)\end{array}$ & $\begin{array}{c}\text { Total } \\
\text { carbohydrate } \\
(\%)\end{array}$ \\
\hline 12.12 & 8.00 & 0.74 & 2.15 & 76.99 \\
\hline
\end{tabular}

Blackberry seed sample used for analysis contained $12.12 \%$ moisture, $8.00 \%$ protein, $0.74 \%$ fat, $2.15 \%$ ash and $76.99 \%$ total carbohydrate in wet weight basis. The proximate composition of different plants are influenced by a number of factors such as species, genus, variety whereas extrinsic factors such as environmental, storage and others. All these factors play an important role in this proximate composition. Moreover, experimental error may also be responsible for such variation (Pompeu et al., 2009).

\section{Photochemical parameters of blackberry seed}

Two different solvents (absolute acetone and absolute ethanol) and two different techniques (hot extraction and cold extraction) were used for determining the amounts of antioxidant extracts from blackberry seed and the results are shown in Table 2.

Table 2: Amount of extracts from different solvents

\begin{tabular}{|c|c|c|c|c|c|c|}
\hline \multicolumn{7}{|c|}{ Cold extraction (room temperature) } \\
\hline $\begin{array}{c}\text { Solve } \\
\text { nt }\end{array}$ & $\begin{array}{l}\mathrm{Ti} \\
\mathrm{me} \\
\text { (hr } \\
\text { s) }\end{array}$ & $\begin{array}{l}\text { Temper } \\
\text { ature } \\
\left({ }^{\circ} \mathrm{C}\right) \\
\text { lall }\end{array}$ & $\begin{array}{l}\text { Sam } \\
\text { ple } \\
(\mathrm{g})\end{array}$ & $\begin{array}{c}\text { Solv } \\
\text { ent } \\
(\mathrm{ml})\end{array}$ & $\begin{array}{c}\text { Dry } \\
\text { extrac } \\
\mathrm{t}(\mathrm{g})\end{array}$ & $\begin{array}{c}\% \text { of } \\
\text { extra } \\
\text { ct } \\
\text { obtai } \\
\text { ned }\end{array}$ \\
\hline $\begin{array}{l}\text { Acet } \\
\text { one }\end{array}$ & 48 & $1127^{\circ} \mathrm{C}$ & 25 & 200 & 1.070 & 4.28 \\
\hline $\begin{array}{c}\text { Etha } \\
\text { nol }\end{array}$ & 48 & $27^{\circ} \mathrm{C}$ & 25 & 200 & 1.797 & 7.19 \\
\hline \multicolumn{7}{|c|}{ Hot extraction $\left(40^{\circ} \mathrm{C}\right)$} \\
\hline Solve & $\begin{array}{l}\mathrm{Ti} \\
\mathrm{me} \\
(\mathrm{hr} \\
\mathrm{s})\end{array}$ & $\begin{array}{c}\text { Temper } \\
\text { ature } \\
\left({ }^{\circ} \mathrm{C}\right)\end{array}$ & $\begin{array}{l}\text { Sam } \\
\text { ple } \\
(\mathrm{g})\end{array}$ & $\begin{array}{c}\text { Solv } \\
\text { ent } \\
(\mathrm{ml})\end{array}$ & $\begin{array}{c}\text { Dry } \\
\text { extrac } \\
\mathrm{t}(\mathrm{g})\end{array}$ & $\begin{array}{c}\% \text { of } \\
\text { extra } \\
\text { ct } \\
\text { obtai } \\
\text { ned }\end{array}$ \\
\hline $\begin{array}{c}\text { Acet } \\
\text { one }\end{array}$ & 48 & $40^{\circ} \mathrm{C}$ & 25 & 200 & 1.088 & 4.35 \\
\hline $\begin{array}{c}\text { Etha } \\
\text { nol }\end{array}$ & 48 & $40^{\circ} \mathrm{C}$ & 25 & 200 & 1.869 & 7.48 \\
\hline
\end{tabular}

From Table 2, it is seen that the acetone extract (for cold extraction) was found to be $4.28 \%$, while ethanol extracts (for cold extraction) was $7.19 \%$. It indicates that percentage of extract increased by $67.99 \%$ in case of ethanol extract in comparison to acetone extract. In case of hot extraction process, the acetone extract was found to be $4.35 \%$, while ethanol extract was $7.48 \%$. It indicates that percentage of extract increased by $71.95 \%$ in case of ethanol extract in comparison to acetone extract. Same observation was demonstrated by Milan and Stankovic (2011). Sultana et al. (2007) found maximum extracts from different medicinal 
plants with ethanol than other solvents used like acetone. Hsu and Coupar (2006) reported that this variation might be due to the different availability of extractable components, resulting from various chemical compositions of solvent used.

Results also revealed that between the two techniques (hot and cold extraction), efficiency of the hot extraction is slightly higher than cold extraction (1.02 times for acetone and 1.04 times for ethanol) which indicates that hot extraction system is somewhat more efficient for the recovery of antioxidant components than cold extraction system. The result is more or less similar with the findings of Shon et al. (2004) who investigated that alcoholic solvent and hot extraction method are more efficient to extract antioxidant compounds from Phellinus baumii. Chata et al. (2006) reported that hot extraction performed under $40^{\circ} \mathrm{C}$ helps to mix the solvent with solution properly which was responsible to extract the phenolic component by solvent. Yen et al. (2004) concluded that hot extraction at $40^{\circ} \mathrm{C}$ does not affect the loss of phenolic content as the temperature is mild temperature.

\section{Amount of total phenolic content (TPC) in blackberry seed}

To determine the total phenolic contents (mg gallic acid equivalent per gram of dry extract) in blackberry seed for acetone and ethanol extract a regression equation (1) developed by using standard curve (Figure 1) and the result is shown in Figure 3.

$\mathrm{y}=6.975 \mathrm{x}-0.0152 \ldots \ldots \ldots \ldots . .(1)$, where $\mathrm{y}$ indicates absorbance at $765 \mathrm{~nm}$ and $\mathrm{x}$ indicates the concentration of gallic acid in $\mu \mathrm{g} / \mathrm{ml}$.

From figure 3 , it is seen that HEE gave the highest phenolic content as $56.56 \mathrm{mg}$ Gallic Acid Equivalent (GAE)/gm of dry extract, and is followed by CEE with $38.00 \mathrm{mg}$ GAE/gm of dry extract. HAE gave the total phenolic content with $38.83 \mathrm{mg}$ GAE/gm of dry extract and the lowest phenolic content $33.21 \mathrm{mg}$ GAE/gm of dry extract was given by CAE. From the results it can be shown that, the difference between hot and cold extraction using ethanol is comparatively higher than the difference between hot and cold extraction using acetone. So, the solvent effect is quite high. For cold extraction, TPC from CEE is 1.14 times higher than CAE and TPC from HEE is 1.46 times higher than HAE. These observations can be compared with the findings of Deepika et al. (2011), who reported total phenolic content of jackfruit seed as $1.45 \pm 0.007 \mu \mathrm{g} \mathrm{GAE} / \mathrm{mg}$ for acetone extract and $2.12 \pm 0.009 \mu \mathrm{g}$ GAE/ $\mathrm{mg}$ for ethanol extract. This variation may be due to the fact that, phenolics are often extracted in better amounts in more polar solvents such methanol, ethanol than other solvents such as acetone (Siddhuraju and Becker, 2003; Anwar et al., 2006; Sultana et al., 2007).

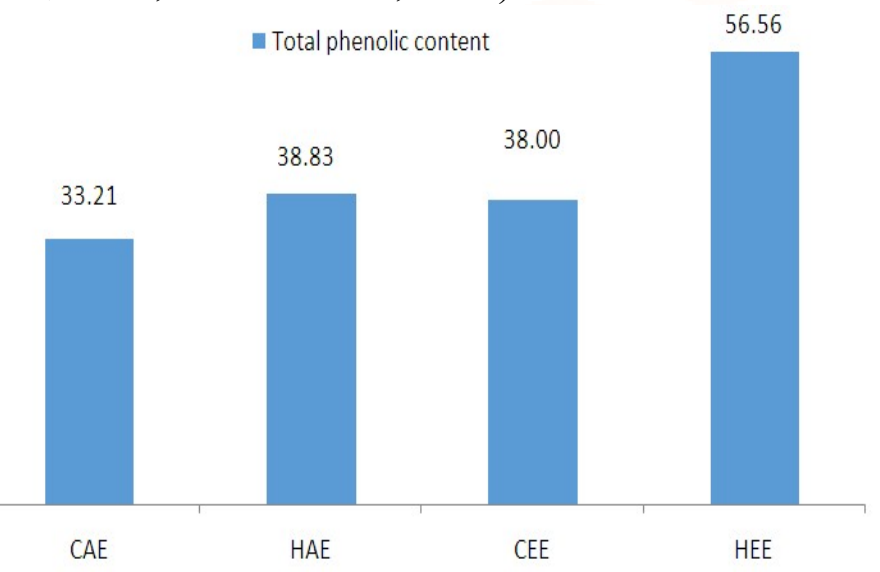

Figure 3: Total phenolic content of different solvent extracts of blackberry seed.

Here, $\mathrm{CAE}=$ Cold acetone extract $\left(26^{\circ} \mathrm{C}\right), \mathrm{HAE}=\mathrm{Hot}$ acetone extract $\left(40^{\circ} \mathrm{C}\right), \mathrm{CEE}=\mathrm{Cold}$ ethanol extract $\left(26^{\circ} \mathrm{C}\right), \mathrm{HEE}=$ Hot ethanol extract $\left(40^{\circ} \mathrm{C}\right)$.

The phenolic contents in blackberries can vary due to different production factors, including genetics and environmental conditions (Fan- chiang and Wrolstad, 2005). It was reported that the extraction efficiency depends on the affinity between the solvent and the phenolic groups (Hayouni et al., 2007; Ignat et al., 2011).

\section{Total antioxidant capacity of different extracts of blackberry seed}

The standard calibration curve of ascorbic acid for the determination of total antioxidant capacity in different solvent extracts of blackberry seed was developed in Figure 2 and from those data the following regression equation was developed-

$\mathrm{y}=0.003 \mathrm{x}-0.020 \ldots \ldots \ldots \ldots$ (2), where $\mathrm{y}$ is absorbance at $695 \mathrm{~nm}$ and $\mathrm{x}$ is concentration in $\mu \mathrm{g} / \mathrm{ml}$.

By using equation (2) total antioxidant capacity of different solvent extracts was determined as ascorbic acid equivalent per gram of dry extract (AAE/g) and shown in Figure 4. The highest TAC was obtained from HEE (82.42 AAE/g) while CAE gave lowest value (75.46 AAE/g). Again between the ethanol extracts, HEE gave slightly high ascorbic acid equivalent (AAE) which was 1.07 times more than $\mathrm{CEE}$ and between the acetone extract, HAE gave 1.06 times more AAE than CAE. So in this case we may conclude that, HEE is the most efficient among the 
solvent extracts tested. These results are in concordance with the findings of Soong and Barlow (2004), who measured the antioxidant capacity in different fruit portions. According to his findings, the seeds were showed a much higher antioxidant activity than the edible portions, e.g. jackfruit seed, tamarind seed, avocado seed contained antioxidant capacity as 7.4, 698, 236 AAE $(\mu \mathrm{mol} / \mathrm{g})$ while their edible portion contained antioxidant capacity as 3, 17, 4.9 $\mathrm{AAE}(\mu \mathrm{mol} / \mathrm{g})$.

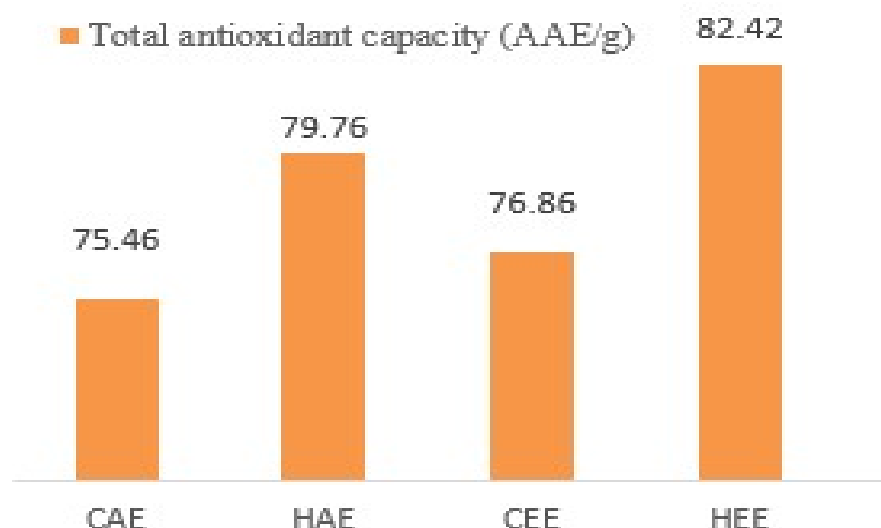

Figure 4: Total antioxidant capacity of different solvent extracts of blackberry seed

\section{Reducing power assay of different extracts of blackberry seed}

The data of reducing power assay (as absorbance at $700 \mathrm{~nm}$ ) for different extracts of blackberry seed with hot and cold technique were plotted in a linear graph ( Figure 5 and 6) as absorbance at $700 \mathrm{~nm}$ on $\mathrm{Y}$ - axis and concentration of extract $(\mu \mathrm{g} / \mathrm{ml})$ on $\mathrm{X}$ - axis.

Figure 5 shows the comparison of reducing power assay of CAE (cold acetone extract at $26^{\circ} \mathrm{C}$ ) and HAE (hot acetone extract at $40^{\circ} \mathrm{C}$ ) of blackberry seed. It is seen that the reducing power of both $\mathrm{CAE}$ and $\mathrm{HAE}$ of blackberry seed was found to increase with the increasing extract concentration. Maximum absorbance of 0.25 for HAE and 0.23 for CAE were observed at extract concentration of $250 \mu \mathrm{g} / \mathrm{ml}$. Thus HAE gave 1.09 times more reducing power than $\mathrm{CAE}$ at $250 \mu \mathrm{g} / \mathrm{ml}$ extract concentration. The results can be compared with the findings of Yeasmen and Islam (2015), who conducted research with tamarind seed and found that the reducing power of both HAE and CAE of $T$. indica seed was increased with the increased extract concentration. The findings also admitted that the maximum absorbance for HAE and CAE were 0.66 and 0.64 respectively at extract concentration of $500 \mu \mathrm{g} / \mathrm{ml}$.
Figure 6 shows the comparison of reducing power assay of CEE (cold ethanol extract at $26^{\circ} \mathrm{C}$ ) and $\mathrm{HEE}$ (hot ethanol extract at $40^{\circ} \mathrm{C}$ ) of blackberry seed. It is seen that the reducing power of both CEE and HEE of blackberry seed increased with the increasing extract concentration. Maximum absorbance of 0.26 for HEE and 0.23 for CEE were observed at extract concentration of $250 \mu \mathrm{g} / \mathrm{ml}$. It is found that, HEE gave 1.13 times more reducing power than CEE at $250 \mu \mathrm{g} / \mathrm{ml}$ extract concentration.

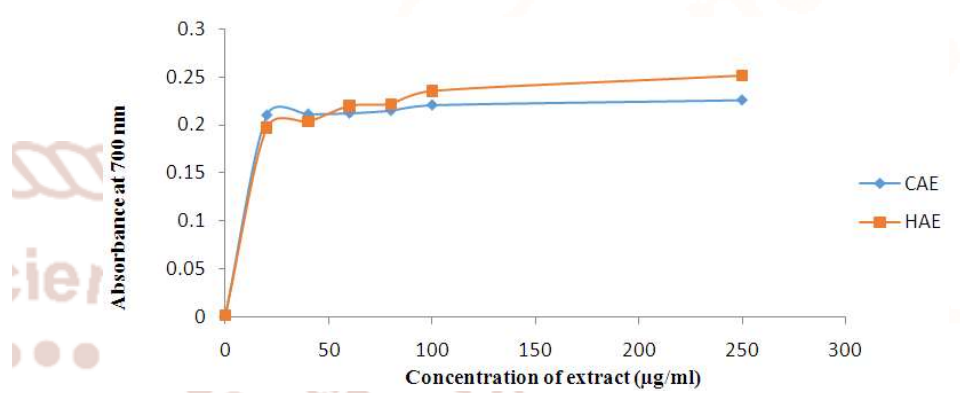

Figure 5: Reducing power assay of CAE and HAE of

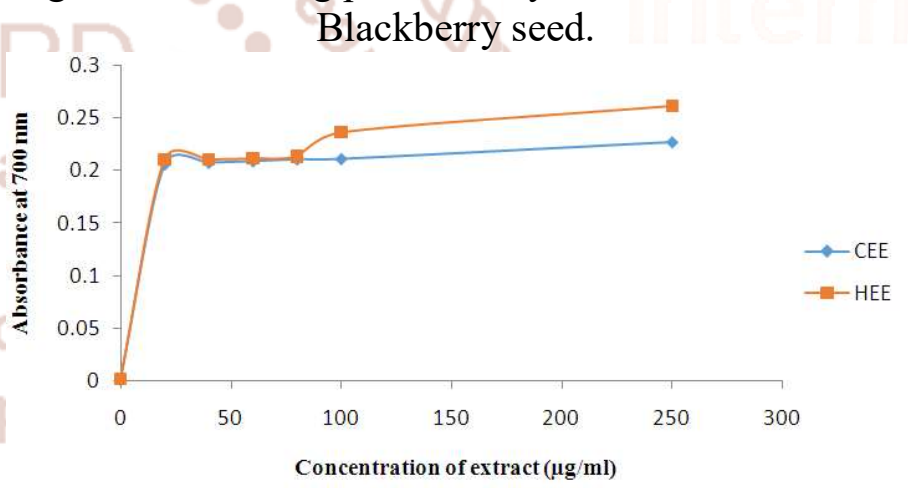

Figure 6: Reducing power assay of CEE and HEE of Blackberry seed

The results can be compared with the findings of Yeasmen and Islam (2015), who conducted research with tamarind seed and found the maximum absorbance for HEE and CEE were 0.7702 and 0.7328 respectively at extract concentration of $500 \mu \mathrm{g} / \mathrm{ml}$. Comparing the result between the above section it is clearly seen that, reducing power assay for both hot and cold ethanol extracts of blackberry seed is found considerably higher compared to the corresponding acetone extracts (e.g. 0.26 for HEE vs. 0.25 for HAE). In the previous graph it is shown that reducing power of hot ethanol and acetone extract is higher than the reducing power of cold ethanol and acetone extract. Thus hot ethanol and acetone extracts were compared with ascorbic acid (standard) in the next section as far reducing power is concerned. 
Comparison of reducing power assay of hot ethanol and acetone extracts with ascorbic acid (standard)

Figure 7 shows the comparison of hot ethanol and acetone extracts with ascorbic acid (standard) for reducing power assay represented as absorbance at $700 \mathrm{~nm}$. It is seen that for both of the hot extracts, the higher the concentration of extracts the higher the reducing power (absorbance at $700 \mathrm{~nm}$ ) as mentioned earlier and that the reducing power (absorbance at 700 $\mathrm{nm})$ is quite higher for ascorbic acid for each concentration level tested.

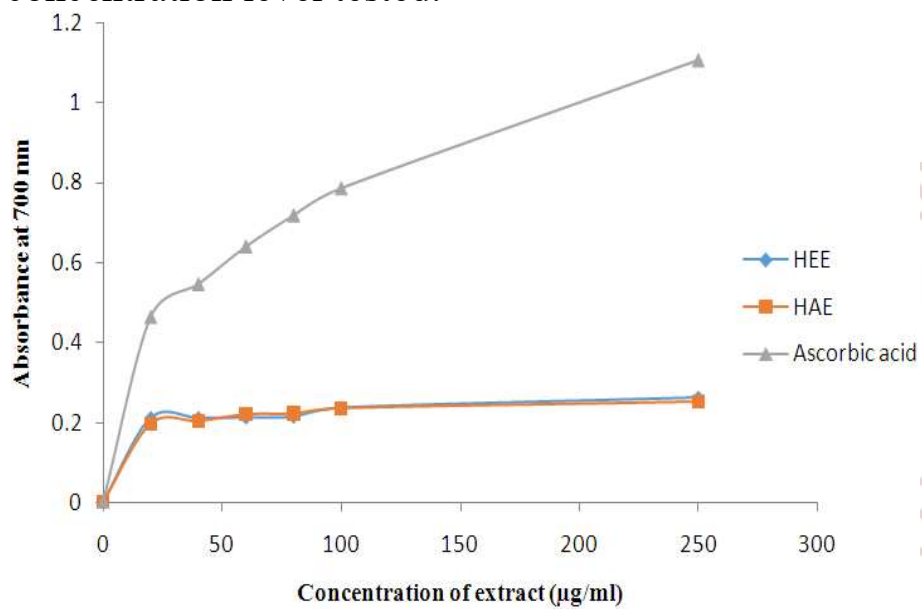

Figure 7: Reducing power assay of hot ethanol and acetone extracts with standard.

The maximum absorbance for ascorbic acid is 1.48 compared to 0.26 and 0.25 for hot ethanol and acetone extract respectively at concentration level of $250 \mu \mathrm{g} / \mathrm{ml}$. Thus it is found that the reducing power for ascorbic acid is undoubtedly higher than the tested extracts - ethanol and acetone. The highest reducing power is given by $\mathrm{HEE}$ among the tested extracts (CEE, HAE and CAE) except standard. These results can be compared with the findings of Deepti et al. (2013), who conducted research with tamarind seed and showed that at concentration of $500 \mu \mathrm{g} / \mathrm{ml}$ ethanol extracts of tamarind seed gave the reducing power as 0.71 which continued to increase with the increasing concentration such that at 600,700 and $800 \mu \mathrm{g} / \mathrm{ml}$ concentration, the absorbance values were 1.7, 1.9 and 2 respectively. Sultana et al. (2007) found reducing power (at absorbance $700 \mathrm{~nm}$ ) of ethanol extract of Aloe barbadensis bark as 1.56 under cold extraction and 1.72 under hot extraction.

\section{CONCLUSION}

The results of the present investigation showed that the ethanol and acetone extracts of blackberry seed, extracted by hot $\left(40^{\circ} \mathrm{C}\right)$ extraction technique exhibited better antioxidant activities and phenolic contents in comparison to cold ethanol and acetone extracts of blackberry seed $(7.48 \%$ vs. $7.19 \%$ for ethanol and
$4.35 \%$ vs. $4.28 \%$ for acetone). Hot extraction also exhibited more reducing power assay than cold extraction. The obtained data would certainly help to determine the potency of blackberry seed as a potential source of natural antioxidant to be used for functional food applications. So, future research program and planning could be taken to separate individual components responsible for antioxidant activity and ensure their applications for welfare of human and animals.

\section{ACKNOWLEDGEMENT:}

The authors acknowledge with thanks for the financial assistance received to carry out the study from the National Science and Technology (NST) fellowship under Ministry of Science and Technology, Bangladesh.

\section{REFERENCES:}

1. Amarowicz R, Estrella I, Hernandez T, Robredo S, Troszynskas A, Kosinka A, Pegg RB. 2010. Free radical-scavenging capacity, antioxidant activity and phenolic composition of green lentil (Lens culinaris). Food Chemistry, 121 (3): 705711.

2. Anwar F, Jamil A, Iqbal S, Sheikh MA. 2006. Antioxidant activity of various plant extracts under ambient and accelerated storage of sunflower oil. Grasas Aceites Sevilla, 57: 189197.

3. AOAC. 2005. Official methods of Analysis of Analytical Chemists, $18^{\text {th }}$ edition, Association of Official Analytical Chemists. Washington DC, USA.

4. AOAC. 2012. Official methods of Analysis of Analytical Chemists, $19^{\text {th }}$ edition. Association of Official Analytical Chemists. Washington DC, USA.

5. Arabshahi-Delouee S, Urooj A. 2006. Antioxidants properties of various solvent extracts of mulberry. Food Chemistry, 102: 1233-1240.

6. Balasundram NK, Sundram, Samman S. 2006. Phenolic compounds in plants and agri-industrial by-products: antioxidant activity, occurrence, and potential uses. Food Chemistry, 99: 191-203.

7. Baydar NG, Ozkan G, Yasar S. 2006. Evaluation of the antiradical and antioxidant potential of grape extracts. Food Control, 18: 1131-1136.

8. Bucic-Kojic A, Planinic M, Tomas S, Jakobek L, Seruga M. 2009. Influence of solvent and 
International Journal of Trend in Scientific Research and Development (IJTSRD) ISSN: 2456-6470

temperature on extraction of phenolic compounds from grape seed, antioxidant activity and colour of extract. International Journal of Food Science and Technology, 44: 2394-2401.

9. Chata SAS, Anwar F, Manzoor M, Bajwa JR. 2006. Evaluation of the antioxidant activity of rice bran extracts using different antioxidant assays. Grasas Aceites Sevilla, 57: 328-335.

10. Coda R, Rizzello CG, Pinto D, Gobbetti M. 2012. Selected lactic acid bacteria synthesize antioxidant peptides during sour dough fermentation of cereal flours. Applied and Environmental Microbiology, 78(4):1087-1096.

11. Deepika G, Sonia M, Avijit S, Rajinder KG. 2011. Phytochemical nutritional and antioxidant activity evaluation of seed of jackfruit (Artocarpus heterophyllus). International Journal of Pharma and Bio Sciences, 5: 25-26.

12. Deepti B, Mayuri, Ashish M, Nilam M. 2013. Evaluation of anti- inflammatory and analgesic activity of tamarind (Tamarindus indica l.) seeds. International Journal of Pharmacy and Pharmaceutical Science, 5: 30-38.

13. Dehpour AA, Ebrahimzadeh MA, Nabavi SF, Nabavi SM. 2009. Antioxidant activity of methanol extract of Ferula assafoetida and its essential oil composition. Grasas Aceites, 60: 405412.

14. Fan- Chiang HJ, Wrolstad RE. 2010. Sugar and nonvolatile acid composition of blackberries. $J$. AOAC Int. 93: 956-965.

15. Ghosal S, Bhattacharya A, Bhattacharya SK. 2003. Antioxidant effects of Emblica officinal is and their biological consequences. In Recent Progress in Medicinal Plants vol. 8 (Majumdar DK, Govil JN and Singh VK eds.). Studium Press. pp. 149.

16. Haleem MA, Barton KL, Borges G, Crozier A, Anderson AS. 2008. Increasing antioxidant intake from fruits and vegetables: Practical strategies for the Scottish population. Journal of Human Nutrition and Dietetics, 21: 539-546.

17. Hayouni EA, Abebradda M, BouixM, Hamdi M. 2007. The effects of solvents and extraction method on the phenolic contents and biological activities in vitro of Tunisian Quercus coccifera $\mathrm{L}$. and Juniperus phoenicea L. fruit extracts. Food Chemistry, 105(3): 1126-1134.
18. Hsu B, Coupar IM. 2006. Antioxidant activity of hot water extract from the fruit of the Doum palm, Hyphaene thebaica. Food Chemistry, 98: 317-328.

19. Huang W, Zhang H, Liu W, Li C. 2012. Survey of antioxidant capacity and phenolic composition of blueberry, blackberry, strawberry in Nanjing. Univ. Sci. B Biomed Biotechnology, 13(2): 94102.

20. Ignat I, Volf I, Popa VI. 2011. A critical review of methods for characterization of polyphenolic compounds in fruits and vegetables. Journal of Food Chemistry, 126(4): 1821-1835.

21. Imran M, Khan M. 2014. Qualitative and quantitative characterization of phytoconstituents from fruits of Stereospermum colais (buch.-ham. exdillwyn) mabb. Indo American journal of Pharmaceutical Research, 4: 3280-3285.

22. Jayaprakasha GK, Selvi T, Sakariah KK. 2003. Antibacterial and antioxidant activities of grape (Vitis vinifera) seed extracts. Food Research International, 36: 117-122.

23. Kaume L, Howard LR, Devareddy L. 2012. The blackberry fruit: a review on its composition and chemistry, metabolism and bioavailability, and health benefits. Journal of Agricultural and Food Chemistry Davis, 60(23):5716-5727.

24. Llobera A. 2012. Study on the antioxidant activity of grape stems (Vitis vinifera). A preliminary assessment of crude extracts. Food and Nutrition Sciences, 3(4): 500-504.

25. Marinova EM, Yanishlieva NV. 2003. Antioxidant activity and mechanism of action of some phenolic acid at an ambient and high temperatures. Journal of Food Chemistry, 81: 189-197.

26. Matthias OA, Philip FU, Uchenna NAN, Chidozie UEO, Uchenna BO, Emmanuel CM. 2015. Antioxidant, total phenolic and flavonoid content of selected Nigerian medicinal plants. Dhaka University Journal of Pharmaceutical Sciences, 14: 34-41.

27. Milan S, Stankovic. 2011. Total phenolic content, flavonoid concentration and antioxidant activity of Marrubium peregrinuml extracts. Kragujevac. Journal of Science, 33: 63-72.

28. Ozen T, Demirtas I, Aksit H. 2011. Determination of antioxidant activities of various extracts and 
essential oil compositions of Thymuspraecox subsp. Food Chemistry, 124(1): 58-64.

29. Pompeu DR, Silva EM, Rogez SH. 2009. Optimization of the solvent extraction of phenolic antioxidants from fruits of Euterpeoleracea using response surface methodology. Bioresource Technology, 100: 6076-6082.

30. Prasad KN, Hassan FA, Yang B, Kong KW, Ramanan RN, Azlan A, Ismail A. 2011. Response surface optimisation for the extraction of phenolic compounds and antioxidant capacities of underutilized Mangifera pajangKosterm peels. Food Chemistry, 128(4): 1121-1127.

31. Saha J, Debnath M, Saha A, Ghosh T, Sarkar PK. 2011. Response surface optimisation of extraction of antioxidants from strawberry fruit, and lipid peroxidation inhibitory potential of the fruit extract in cooked chicken patties. Journal of the Science of Food and Agriculture, 91(10):17591765.

32. Shon MY, Cho SD, Kohng GG, Nam SH, Sung NJ. 2004. Antimutagenic, antioxidant and free radical scavenging activity of ethyl acetate extracts from white, yellow and red onion. Food Chemistry, 42: 659-666.

33. Siddhuraju P, Becker K. 2003. Antioxidant properties of various extracts of total phenolic constituents from three different agroclimatic origins of drumstick tree (Moringa oleifera lam.) leaves. Journal of Agricultural and Food Chemistry, 51: 2144-2155.

34. Singh N, Rajini PS. 2004. Free radical scavenging activity of an aqueous extract of potato peel. Journal of Food Chemistry, 85(4): 611-616.

35. Srivastava RP and Sanjeev K. 2002. Fruit and Vegetable Preservation Principles and Practices. Third Revised and Enlarged Edition, International Book Distribution Co. pp. 353-364.
36. Soong YY, Barlow PJ. 2004. Antioxidant activity and phenolic content of selected fruit seeds. Food Chemistry, 88: 411-417.

37. Subramanion LJ, Zuraini Z, Sasidharan S. 2011. Phytochemicals screening, DPPH free radical scavenging and xanthine oxidase inhibitiory activities of Cassia fistula seeds extract. Journal of Medicinal Plants, 5: 1941 -1947.

38. Sultana B, Anwar F, Przybylski R. 2007. Antioxidant activity of phenolic components present in barks of barks of Azadirachtaindica, Terminaliaarjuna, Acacia nilotica, and Eugenia jambolana Lam. trees. Food Chemistry, 104: 1106-1114.

39. Wang SY, Lin HS. 2000. Antioxidant activity in fruits and leaves of blackberry, raspberry, and strawberry varies with cultivar and developmental stage. Journal of Agricultural and Food Chemistry, 48: 140-146.

40. Yeasmen N, Islam MN. 2015. Ethanol as a solvent and hot extraction technique preserved the antioxidant properties of tamarind (Tamarindus indica) seed. Journal of Advanced Veterinary and Animal Research, 2(3): 332-337.

41. Yen GC, Duh PD, Su HJ. 2004. Antioxidant properties of lotus seed and its effect on DNA damage in human lymphocytes. Food Chemistry, 89: 379-385.

42. Zhao J, Liu T, Ma-Long, Yan M, Gu-Zheng Y, Huang Y, Xu-Fang, Zhao, Huang Y, Xu- Fang, Zhao Y. 2011. Antioxidant and preventive effects of extract from Nymphaeacandida flower on in vitro immunological liver injury of rat primary hepatocyte cultures. Evidence based Complementary and Alternative Medicine Article ID 497673. 